\title{
ADVANCED OXIDATION PROCESSES FOR FOOD INDUSTRIAL WASTEWATER DECONTAMINATION
}

\author{
Dorota Krzemińska', Ewa Neczaj', Gabriel Borowski²
}

1 Institute of Environmental Engineering, Czestochowa University of Technology, Brzeznicka 60a, 42-200 Czestochowa, Poland, e-mail: dkrzeminska@is.pcz.czest.pl

2 Faculty of Fundamentals of Technology, Lublin University of Technology, Nadbystrzycka 38, 20-618 Lublin, Poland, e-mail: g.borowski@pollub.pl

Received: 2014.12 .27

Accepted: 2015.02.04

Published: 2015.04.01

\begin{abstract}
High organic matter content is a basic problem in food industry wastewaters. Typically, the amount and composition of the effluent varies considerably. In the article four groups of advanced processes and their combination of food industry wastewater treatment have been reviewed: electrochemical oxidation (EC), Fenton's process, ozonation of water and photocatalytic processes. All advanced oxidation processes (AOP's) are characterized by a common chemical feature: the capability of exploiting high reactivity of $\mathrm{HO}^{*}$ radicals in driving oxidation processes which are suitable for achieving decolonization and odour reduction, and the complete mineralization or increase of bioavailability of recalcitrant organic pollutants.
\end{abstract}

Keywords: advanced oxidation process, wastewater, food industry.

\section{INTRODUCTION}

Industrial wastewater characteristics vary not only between the industries that generate them, but also within each industry. These characteristics are also much more diverse than domestic wastewater, which is usually qualitatively and quantitatively similar in its composition. On the contrary, industry produces large quantities of highly polluted wastewater containing toxic substances, organic and inorganic compounds such as: heavy metals, pesticides, phenols and derivatives thereof, aromatic and aliphatic hydrocarbons, halogenated compounds, etc., which are generally resistant to destruction by biological treatment methods [Meriç et al. 2005, Shu 2006, Ledakowicz et al. 2001, Gogate \& Pandit 2004].

Compared to other industrial sectors, food industry requires great amounts of water, since it is used throughout most of plant operations, such as production, cleaning, sanitizing, cooling and materials transport, among others [Mavrov \& Be1ieres 2000, Cicek 2003, Álvarez et al. 2011].
As a result, meat, poultry, dairy, olive mill etc. processing plants are the facilities producing "difficult" wastewater with large total load of organic pollutants like proteins or fats and chemicals used for cleaning and sanitizing processing equipment [Álvarez et al. 2011, Zhukova et al. 2011].

The wastewater streams with different levels of pollution load (low, medium and high contamination) are collected and treated in an on-site installation or in a municipal sewage treatment plant. Increasing food production will increase the volume of sewage and the cost of disposal for food processing plants and present difficult challenges for municipal wastewater treatment plant operators [Mavrov \& Belieres 2000, Cicek 2003]. Currently, in accordance with the legislation of the European Union introduced more stringent controls and rules concerning pollution of industrial wastewater [Marcucci et al. 2002, Mason 2000]. Due to the adverse impact of even small quantities of these compounds on the organoleptic characteristics of the discharge of waste waters such as colour, odour, taste, etc., as well as a threat to living organisms began to 
look for effective, efficient and economically viable methods to remove them.

In order to achieve these aims the potential and promising methods need to include advanced oxidation methods (AOP's), which include the Fenton reaction, UV photolysis, sonication, ozonation, electrochemical oxidation, etc. These processes involve the generation of highly free radicals, mainly hydroxyl radical (HO') via chemical, photochemical and photocatalytic reactions. Their application is unavoidable for the treatment of refractory organic pollutants. Numerous researches have evaluated on the treatment of refractory compounds by different AOP's [Ledakowicz et al. 2001, Oller et al. 2011, Tarek et al. 2011, Pera-Titus et al. 2004].

The application of AOP's in wastewater treatment leads to the degradation of the pollutant rather than transferring it to another phase, making the relevant technologies effective in the removal of organic pollutants in solution. In recent years, one of the main objectives of these processes mainly with highly polluted effluents has been not to mineralise the pollutant totally (AOP's for complete mineralization are very expensive), but to improve the biodegradability for a possible coupling of the AOP's with a conventional biological treatment process [Sanz et al. 2003, Muñoz et al. 2005].

\section{PROCESSES FOR FOOD INDUSTRY WASTEWATER TREATMENT}

The AOP`s has been used to reduce the organic load or toxicity of wastewaters from different industries. They are based on the generation of hydroxyl free radicals, which have a high electrochemical oxidant potential (Table 1). The generation of hydroxyl radicals involves the combination of classical oxidants, such as $\mathrm{H}_{2} \mathrm{O}_{2}$ or $\mathrm{O}_{3}$ with UV radiation or a catalyst. The formed radicals react with organic materials breaking them down gradually in a stepwise process. The generation of hydroxyl radicals can be achieved by a variety of reactions, such as $\mathrm{O}_{3} / \mathrm{UV}, \mathrm{H}_{2} \mathrm{O}_{2} / \mathrm{UV}$, Fenton reaction, photo-Fenton, $\mathrm{TiO}_{2} / \mathrm{H}_{2} \mathrm{O}_{2} / \mathrm{UV}$ etc. Such integrated solutions can lead to more efficient use of chemical oxidants while reducing the effect of toxic or inhibitory compounds in bioreactors, leading to more robust and stable biological treatment [Gogate \& Pandit 2004, Pera-Titus et al. 2004, Turhan \& Turgut 2009].
Table 1. Oxidizing potential for several chemical oxidizers [Pera-Titus et al. 2004, Turhan \& Turgut 2009]

\begin{tabular}{|l|c|}
\hline \multicolumn{1}{|c|}{ Oxidant } & $\begin{array}{c}\text { Electrochemical } \\
\text { oxidation potential [V] }\end{array}$ \\
\hline Fluorine $\left(\mathrm{F}_{2}\right)$ & 3.03 \\
\hline Hydroxyl radical $(\mathrm{HO} \cdot)$ & 2.80 \\
\hline Atomic oxygen & 2.42 \\
\hline Ozone $\left(\mathrm{O}_{3}\right)$ & 2.07 \\
\hline Hydrogen peroxide $\left(\mathrm{H}_{2} \mathrm{O}_{2}\right)$ & 1.77 \\
\hline Hypobromous acid $\left(\mathrm{H}_{\mathrm{br}} \mathrm{O}\right)$ & 1.59 \\
\hline Chlorine dioxide $\left(\mathrm{ClO}_{2}\right)$ & 1.50 \\
\hline Chlorine $\left(\mathrm{Cl}_{2}\right)$ & 1.36 \\
\hline Oxygen $(\mathrm{molecular})$ & 1.23 \\
\hline Bromine $\left(\mathrm{Br}_{2}\right)$ & 1.09 \\
\hline
\end{tabular}

\section{Elektrochemical oxidation}

It was observed that electrochemical oxidation (EC) has the potential to be a distinct economic and environmental choice for treatment of wastewater and due to strict environmental regulations [Kobya \& Delipinar 2008, Gengec et al. 2012]. EC involves the formation of hydroxyl radicals at the active sites of anode and has been used for the decontamination of various inorganic and organic pollutants [Rizzo 2011]. One of the major advantages of electrochemistry is that on the surface of the electrodes only electrons are produced and consumed, thereby "pure reagents" and do not contribute to a further increase in the number of chemical compounds in the environment, which often takes place in other processes [Zaleska \& Grabowska 2008]. Moreover, advantages of the EC compared to conventional chemical coagulation include reduced wastewater acidification and salinity, low dosage of coagulant, superior coagulant dispersion and intrinsic electroflotation separation capability [Gengec et al. 2012].

The efficiency of electrochemical process depends on electrode and supporting electrolyte types, applied current, solution $\mathrm{pH}$, nature of target contaminant/water matrix and initial concentration of the pollutants [Rizzo 2011]. In the EC process different anodes have been investigated: graphite, $\mathrm{Pt}, \mathrm{TiO}_{2}, \mathrm{IrO}_{2}, \mathrm{PbO}_{2}$, several Ti-based alloys and boron-doped diamond electrodes but the most generally employed as a electrode material is iron $(\mathrm{Fe})$ or aluminium (Al) [Gengec et al. 2012, Rizzo 2011].

Generally, six main processes occur during EC: (1) migration to an oppositely charged electrode (electrophoresis) and aggregation due to 
charge neutralization; (2) the cation or hydroxyl ion $(\mathrm{OH})$ forms a precipitate with the pollutant; (3) the metallic cation interacts with $\mathrm{OH}^{-}$to form a hydroxide, which has high adsorption properties thus bonding to the pollutant (bridge coagulation); (4) the hydroxides form larger lattice-like structures and sweeps through the water (sweep coagulation); (5) oxidation of pollutants to less toxic species; (6) removal by electroflotation or sedimentation and adhesion to bubbles [Kobya \& Delipinar 2008, Roa-Morales et al. 2007].

Details of some food industry wastewater studies with EC performed in recent years are provided in Table 2. EC has been proved to be an efficient method for the treatment of food process wastewater such as distillery and fermentation wastewater [Kannan et al. 2006], yeast wastewater [Kobya \& Delipinar 2008], potato chips manufacturing wastewater [Kobya et al. 2006], restaurant wastewater [Chen et al. 2000], egg process wastewater [Xu et al. 2002], oily wastewater [Calvo et al. 2003], poultry slaughterhouse wastewater [Bayramoglu et al. 2006] and olive oil wastewater [Rodrigo et al. 2010].

\section{Fenton process}

Many AOPs use hydrogen peroxide as the main oxidizing agent, which is a more efficient reagent than gaseous oxygen concerning the contaminants mineralization. Fenton's process has its origin in the discovery reported in 1894 that ferrous ion strongly promotes the oxidation of tartaric acid by hydrogen peroxide. However, only much later the oxidation activity has been ascribed to the hydroxyl radical [Herney-Ramirez et al. 2010].

Oxidation with Fenton's reagent is accomplished with a mixture of ferrous ions and hydrogen peroxide, and it takes advantage of the reactivity of the free hydroxyl radicals produced in acidic solution by the catalytic decomposition of hydrogen peroxide and of the coagulation produced by the ferric hydroxide precipitates [Gogate

Table 2. A brief summary of research studies in which EC were used for treating food industry wastewater

\begin{tabular}{|c|c|c|c|}
\hline $\begin{array}{c}\text { Biological and } \\
\text { chemical treatment }\end{array}$ & Target wastewater & Concluding remarks & References \\
\hline $\begin{array}{l}\text { Aluminium } \\
\text { electrocoagulation } \\
/ \mathrm{H}_{2} \mathrm{O}_{2}\end{array}$ & $\begin{array}{l}\text { Pasta and cookie } \\
\text { processing industrial } \\
\text { wastewater }\end{array}$ & $\begin{array}{l}\text { Under optimal conditions of } \mathrm{pH} 4 \text { and } 18.2 \mathrm{~mA} / \mathrm{m}^{2} \text { current } \\
\text { density, Treatment reduced chemical oxygen demand (COD) } \\
\text { by } 90 \% \text {, biochemical oxygen demand }\left(\mathrm{BOD}_{5}\right) \text { by } 96 \% \text {, total } \\
\text { solids by } 95 \% \text { and fecal coliforms by } 99.9 \% \text {. }\end{array}$ & $\begin{array}{l}\text { [Roa-Morales } \\
\text { et al. 2007] }\end{array}$ \\
\hline $\begin{array}{l}\text { Electrocoagulation } \\
\text { (electrode material Fe } \\
\text { and } \mathrm{Al})\end{array}$ & $\begin{array}{l}\text { Cattle-slaughterhouse } \\
\text { wastewater }\end{array}$ & $\begin{array}{l}\text { In the case of aluminium electrode, polyaluminum chloride } \\
\text { (PAC) was used as the coagulant aid for the aforesaid } \\
\text { purpose. COD removal of } 94.4 \% \text { was obtained by adding } \\
0.75 \mathrm{~g} \text { L/PAC. In the case of iron electrode, EC was } \\
\text { conducted concurrent with the Fenton process. As a result, } \\
81.1 \% \text { COD removal was achieved by adding } 9 \% \mathrm{H}_{2} \mathrm{O}_{2} \text {. }\end{array}$ & [Ün et al. 2009] \\
\hline $\begin{array}{l}\text { Anaerobic } \\
\text { electrocoagulation } \\
(\mathrm{AE}) \text { and }(\mathrm{AAE}) \\
\text { anaerobic-aerobic } \\
\text { electrocoagulation }\end{array}$ & $\begin{array}{l}\text { Baker's yeast } \\
\text { wastewater }\end{array}$ & $\begin{array}{l}\text { The maximum color, COD and TOC were } 88 \%, 48 \% \text { and } \\
49 \% \text { at } 80 \mathrm{~A} / \mathrm{m}^{2}, \mathrm{pH} 4 \text { and } 30 \text { min for } \mathrm{AE} \text { and } 86 \%, 49 \% \text { and } \\
43 \% \text { at } 12.5 \mathrm{~A} / \mathrm{m}^{2}, \mathrm{pH} 5 \text { and } 30 \text { min for } \mathrm{AAE} \text {, respectively. }\end{array}$ & $\begin{array}{c}\text { [Gengec et al. } \\
\text { 2012] }\end{array}$ \\
\hline $\begin{array}{l}\text { Conductive-diamond } \\
\text { electrochemical } \\
\text { oxidation }\end{array}$ & Synthetic melanoidins & $\begin{array}{l}\text { The electrolysis was carried out the in lack of additional } \\
\text { electrolyte (except for carbonates) and in the presence of } \\
\mathrm{NaCl} \text { (ranging from } 17.5 \text { to } 85 \mathrm{mM} \text { ). As it can be observed, } \\
\text { the electrolysis without addition of } \mathrm{NaCl} \text { (it remains around } \\
20 \% \text { of initial COD) while electrolyses with } \mathrm{NaCl} \text { electrolyte } \\
\text { obtain the complete removal of COD. }\end{array}$ & $\begin{array}{c}\text { [Canizares et al } \\
\text { 2009] }\end{array}$ \\
\hline $\begin{array}{l}\text { Electrocoagulation } \\
\text { (electrode material Fe } \\
\text { and } \mathrm{Al})\end{array}$ & $\begin{array}{l}\text { Baker's yeast } \\
\text { wastewater }\end{array}$ & $\begin{array}{l}\text { The maximum removal efficiencies of COD, TOC and } \\
\text { turbidity under optimal operating conditions, i.e., } \mathrm{pH} 6.5 \\
\text { for }(\mathrm{Al}) \text { and } \mathrm{pH} 7 \text { for }(\mathrm{Fe}) \text {, current density of } 70 \mathrm{~A} / \mathrm{m}^{2} \text { and } \\
\text { operating time of } 50 \text { min were } 71,53 \text { and } 90 \% \text { for }(\mathrm{Al}) \text { and } \\
69,52 \text { and } 56 \% \text { for }(\mathrm{Fe}) \text {, respectively. }\end{array}$ & $\begin{array}{c}\text { [Kobya \& } \\
\text { Delipinar 2008] }\end{array}$ \\
\hline $\begin{array}{l}\text { Aluminium } \\
\text { electrocoagulation }\end{array}$ & $\begin{array}{l}\text { Moroccan olive mill } \\
\text { wastewater }\end{array}$ & $\begin{array}{l}\text { Electrolysis time } 15 \mathrm{~min}, \mathrm{NaCl} \text { concentration } 2 \mathrm{~g} / \mathrm{L} \text {, initial } \\
\mathrm{pH} 4.2 \text { and current density } 250 \mathrm{~A} / \mathrm{m}^{2} \text {,the discoloration of } \\
\text { the effluent, the reduction of the COD and the reduction of } \\
\text { polyphenols exceeded } 70 \% \text {, the electrodes consumption was } \\
0.085 \mathrm{~kg} \mathrm{Al} / \mathrm{kg} \mathrm{COD}_{\text {removed }}\end{array}$ & $\begin{array}{l}\text { [Hanafi et al. } \\
\text { 2010] }\end{array}$ \\
\hline $\begin{array}{l}\text { Electrochemical } \\
\text { oxidation (boron- } \\
\text { doped diamond } \\
\text { (BDD) as anode) }\end{array}$ & $\begin{array}{l}\text { Sinapinic acid (repre- } \\
\text { sentative polyphenolic } \\
\text { type compounds } \\
\text { present in olive oil mill } \\
\text { wastewater) }\end{array}$ & $\begin{array}{l}\text { Under optimal experimental conditions of flow rates (i.e. } \\
300 \mathrm{~L} / \mathrm{h}) \text {, temperature }\left(\mathrm{T}=50^{\circ} \mathrm{C}\right) \text { and current density (i.e. } \\
\left.10 \mathrm{~mA} / \mathrm{cm}^{2}\right), 97 \% \text { of COD was removed in } 3 \mathrm{~h} \text { electrolysis, } \\
\text { with } 17 \mathrm{kWh} / \mathrm{m}^{3} \text { energy consumption. }\end{array}$ & $\begin{array}{l}\text { [Elaoud et al. } \\
\text { 2011] }\end{array}$ \\
\hline
\end{tabular}


\& Pandit 2004, Pera-Titus et al. 2004, Canizares et al. 2009].

The mechanism of the Fenton's process is quite complex, and some papers can be found in the literature where tens of equations are used for its description (Eq. 1) [Mert et al. 2010].

$$
\mathrm{Fe}^{2+}+\mathrm{H}_{2} \mathrm{O}_{2} \rightarrow \mathrm{Fe}^{3+}+\mathrm{OH}^{-}+\mathrm{OH}^{\cdot}
$$

As iron(II) acts as a catalyst, it has to be regenerated, which seems to occur through the following scheme [Pérez et al. 2002, Rivas et al. 2003]:

$$
\begin{gathered}
\mathrm{Fe}^{3}+\mathrm{H}_{2} \mathrm{O}_{2} \rightarrow \mathrm{Fe}^{2+}+\mathrm{HO}^{2 \cdot}+\mathrm{H}^{+} \\
\mathrm{Fe}^{3}+\mathrm{HO}_{2} \rightarrow \mathrm{Fe}^{2+}+\mathrm{O}_{2}+\mathrm{H}^{+}
\end{gathered}
$$

The photo-Fenton process, as its name suggests, is rather similar to the Fenton one, but employing also radiation [Tokumura et al. 2006].

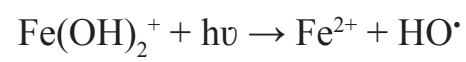

Its effectiveness is attributed to the photolysis of $\mathrm{Fe}(\mathrm{III})$ cations in acidic media yielding $\mathrm{Fe}(\mathrm{II})$ cations (Eq. 4). In this process, the regeneration of $\mathrm{Fe}^{2+}$ by photo-reduction of $\mathrm{Fe}^{3+}$ is accelerated, this photo-reduction being an additional source of highly oxidative hydroxyl radicals, as compared with the "simple" Fenton's process [HerneyRamirez et al. 2010, Stasinakis 2008].

The major parameters affecting Fenton process are solution's $\mathrm{pH}$, amount of ferrous ions, concentration of $\mathrm{H}_{2} \mathrm{O}_{2}$, initial concentration of the pollutant and presence of other ions [Mert et al. 2010, Stasinakis 2008, de Sena et al. 2009].

The main advantage of the process is degradation organic as well as inorganic pollutants that will leading to high mineralization levels [Sanz et al. 2003, Canizares et al. 2009, Stasinakis 2008, de Sena et al. 2009, Martins et al. 2011]. Among the advanced oxidation processes, the easy-to-handle Fenton's reaction has proven to be more effective in terms of removal rate as well as operating expenses for the treatment of toxic and/or refractory food industrial wastewater (Table 3) such as baker's yeast industry effluents [Altinbas 2003], juice wastewater [Amora et al. 2012], meat industry wastewater [de Sena et al. 2009], coffee effluent [Tokumura et al. 2008], winery and distillery wastewater [Oller et al. 2011], olive mill wastewater [Zor-

\begin{tabular}{|c|c|c|c|}
\hline $\begin{array}{c}\text { Biological and } \\
\text { chemical treatment }\end{array}$ & Target wastewater & Concluding remarks & References \\
\hline Fenton's oxidation & $\begin{array}{l}\text { Baker's yeast industry } \\
\text { effluents }\end{array}$ & $\begin{array}{l}\text { The best dosage was } 1200 \mathrm{mg} / \mathrm{L} \mathrm{Fe}^{2+} / 800 \mathrm{mg} / \mathrm{L} \mathrm{H}_{2} \mathrm{O}_{2} \text { at } \mathrm{pH} 4 \\
\text { and in reaction time of } 20 \mathrm{~min} \text { for mineralization of } \mathrm{DOC} \text { and } \\
\text { COD. For these conditions, The maximum color, DOC and } \\
\text { COD were } 99 \%, 90 \% \text { and } 88 \% \text {. }\end{array}$ & $\begin{array}{l}\text { [Pala \& Erden } \\
\text { 2005] }\end{array}$ \\
\hline $\begin{array}{l}\text { Photo-Fenton } \\
\text { oxidation }\end{array}$ & $\begin{array}{l}\text { Synthetic apple-juice } \\
\text { wastewater }\end{array}$ & $\begin{array}{l}\text { At the selected operation conditions ( } 5800 \mathrm{ppm} \mathrm{H}_{2} \mathrm{O}_{2}, 40 \mathrm{ppm} \\
\left.\mathrm{Fe}^{2+}, \mathrm{pH} 4.2 \text { and } 26^{\circ} \mathrm{C}\right), 91 \% \text { mineralization was achieved in } \\
40 \text { min when treating a synthetic wastewater with } 700 \mathrm{ppm} \\
\text { of the total organic carbon (TOC). }\end{array}$ & $\begin{array}{l}\text { [Durán et al. } \\
\text { 2011] }\end{array}$ \\
\hline Fenton's oxidation & Livestock wastewater & $\begin{array}{l}\text { The optimum ratio of } \mathrm{H}_{2} \mathrm{O}_{2}(\mathrm{mg} / \mathrm{L}) \text { to the initial } \mathrm{COD}_{\text {cr }} \text { was } 1.05 \text {. } \\
\text { The optimum initial } \mathrm{pH} \text { were } 3.5-4, \mathrm{H}_{2} \mathrm{O}_{2} / \mathrm{Fe}^{2+} \text { was } 2 \text { and the } \\
\text { optimum reaction time } 30 \text { min. The removal ratios of } \mathrm{COD}_{\text {cr }} \\
\text { and color of the supernatant after static precipitation of the } \\
\text { produced sludge were } 88 \text { and } 95.4 \% \text {, respectively. }\end{array}$ & $\begin{array}{l}\text { [Lee \& Shoda } \\
\text { 2003] }\end{array}$ \\
\hline $\begin{array}{l}\text { Photo-Fenton } \\
\text { oxidation }\end{array}$ & Coffee effluent & $\begin{array}{l}\text { The results suggest that the } \mathrm{UV} / \mathrm{H}_{2} \mathrm{O}_{2} / \mathrm{Fe}^{2+} \text { system is very } \\
\text { efficient for the treatment of coffee effluents. The mineraliza- } \\
\text { tion of } 250 \mathrm{mg} / \mathrm{L} \text { model coffee effluent was not complete but } \\
\text { about } 90 \% \text { mineralization was found after } 200 \text { min of UV } \\
\text { irradiation. }\end{array}$ & $\begin{array}{l}\text { [Tokumura } \\
\text { et al. 2006] }\end{array}$ \\
\hline $\begin{array}{l}\text { Solar photo-Fenton } \\
\text { oxidation }\end{array}$ & Winery wastewaters & $\begin{array}{l}\text { Under optimal conditions, } 61 \% \text { TOC was achieved in } 360 \text { min. } \\
\text { Temperature and initial concentrations of } \mathrm{H}_{2} \mathrm{O}_{2} \text { and oxalic acid } \\
\text { were the most significant factors affecting the wastewater } \\
\text { mineralization. The addition of } \mathrm{H}_{2} \mathrm{O}_{2} \text { can be used to control the } \\
\text { mineralization degree of this type of wastewater. }\end{array}$ & $\begin{array}{l}\text { [Monteagudo } \\
\text { et al. 2012] }\end{array}$ \\
\hline Fenton's oxidation & Synthetic melanoidins & $\begin{array}{l}\text { These high concentrations of refractory carbonis is not able to } \\
\text { achieve the complete mineralization of the waste, and a high } \\
\text { TOC remains at the end of the treatment }(>40 \%) \text {. }\end{array}$ & $\begin{array}{l}\text { [Canizares } \\
\text { et al. 2009] }\end{array}$ \\
\hline $\begin{array}{l}\text { Fenton, Fenton-like } \\
\text { process }\end{array}$ & Olive oil mill wastewater & $\begin{array}{l}\text { Processes showed high COD ( }>80 \%) \text { and total-phenol }(>85 \%) \\
\text { removal performance on evaluated effluents }\end{array}$ & $\begin{array}{l}\text { [Mert et al. } \\
\text { 2010] }\end{array}$ \\
\hline Electro-Fenton & Olive mill wastewater & $\begin{array}{l}\text { Considered as a pre-treatment (COD removal } 53 \% \text { ) before } \\
\text { anaerobic digestion and ultrafiltration resulting in a complete } \\
\text { detoxify of effluent. }\end{array}$ & $\begin{array}{l}\text { [Khoufi et al. } \\
\text { 2009] }\end{array}$ \\
\hline
\end{tabular}
pas \& Costa 2010] etc.

Table 3. A brief summary of research studies in which Fenton process were used for treating food industry wastewater 


\section{Ozonation}

Ozonation of water is a well-known technology and the strong oxidative properties of $\mathrm{O}_{3}$ and its ability to effectively oxidize many organic compounds in aqueous solution have been well documented. Unlike other oxidizing agents such as $\mathrm{Cl}_{2}$, oxidation with $\mathrm{O}_{3}$ leaves no toxic residues that have to be removed or disposed [Sarayu et al. 2007, Ulson de Souza et al. 2010]. Ozonation is one of the AOP processes used to food wastewater treatment, which is versatile and environmentally sound [Sarayu et al. 2007]. Although, the cost of ozone production still is high interest in the use of ozone in wastewater treatment has increased considerably in last few years due to the numerous advantages of this process [Meriç et al. 2005, Ulson de Souza et al. 2010]. Ozonation can eliminate toxic substances, increase the biodegradability of organic pollutants and has high potential in decolourization [Zayas et al. 2007].

Ozone is very reactive towards compounds incorporating conjugated double bonds(such as
$\mathrm{C}=\mathrm{C}, \mathrm{C}=\mathrm{N}, \mathrm{N}=\mathrm{N}$ ), often associated with colour [Gogate \& Pandit 2004, Rizzo 2011, Coca et al. 2007]. Ozone can react with solutes either by direct oxidation between organic contaminants and molecular ozone (Eq. 5) or by indirect reactions with hydroxyl radicals resulting from ozone decomposition (Eq. 6, 7) [Meriç et al. 2005, Rizzo 2011, Coca et al. 2007].

$$
\begin{gathered}
\mathrm{O}_{3}+\mathrm{R} \rightarrow \mathrm{RO}+\mathrm{O}_{2} \\
\mathrm{O}_{3} \leftrightarrow \mathrm{O}+\mathrm{O}_{2} \\
\mathrm{O}+\mathrm{H}_{2} \mathrm{O} \rightarrow 2 \mathrm{HO} .
\end{gathered}
$$

This arises from the fact that $\mathrm{pH}$ affects the double action of ozone on the organic matter which may be a direct or an indirect (free radical) oxidation pathway. At low $\mathrm{pH}$, ozone exclusively reacts with compounds with specific functional groups through selective reactions, such as electrophilic, nucleophilic or dipolar addition reactions (i.e. direct pathway). At basic $\mathrm{pH}$, ozone decomposes yielding hydroxyl radicals, a highly oxidizing species which reacts nonselectively

\begin{tabular}{|c|c|c|c|}
\hline $\begin{array}{c}\text { Biological and chemi- } \\
\text { cal treatment }\end{array}$ & Target wastewater & Concluding remarks & References \\
\hline $\begin{array}{l}\text { Ozonation and aero- } \\
\text { bic biological } \\
\text { degradation }\end{array}$ & Table olive wastewater & $\begin{array}{l}\text { In this combined process, the ozonation of the biologically } \\
\text { pretreated table black-olive wastewater yielded a conver- } \\
\text { sion of } 62 \% \text {, considerably higher than the } 52 \% \text { attained in } \\
\text { the ozonation process. }\end{array}$ & $\begin{array}{l}\text { [Beltran-Heredia } \\
\text { et al. 2000] }\end{array}$ \\
\hline Ozonation & $\begin{array}{l}\text { Six phenolic acids typi- } \\
\text { cally found in olive mill } \\
\text { wastewater }\end{array}$ & $\begin{array}{l}\left(\mathrm{O}_{3} \text { production was varied } 10 \mathrm{~g} / \mathrm{L} \text {, flow rate was } 30 \mathrm{l} / \mathrm{h}\right) \text {. Pro- } \\
\text { cess were effective in degradation of phenolic compounds } \\
91 \% \text {. The COD abatement }(42 \%) \text { proves that ozonation } \\
\text { pathways at those conditions are mainly through partial } \\
\text { oxidation rather than directly to end products }\left(\mathrm{CO}_{2}, \mathrm{H}_{2} \mathrm{O}\right) \text {. }\end{array}$ & $\begin{array}{l}\text { [Martins \& Quinta- } \\
\quad \text { Ferreira 2011] }\end{array}$ \\
\hline Ozonation & $\begin{array}{l}\text { Red-meat-processing } \\
\text { wastewater }\end{array}$ & $\begin{array}{l}\text { The decrease in COD and BOD of the wastewater were } \\
10.7 \% \text { and } 23.6 \% \text {, respectively, decolorization of the } \\
\text { wastewater after ozonation. }\end{array}$ & [Wu \& Doan 2005] \\
\hline Ozonation & Olive mill wastewater & $\begin{array}{l}\text { The ozonation of OMW carried out at three different times } \\
(60,90 \text { and } 120 \mathrm{~min}) \\
\text { The highest efficiencies were achieved at } 120 \mathrm{~min}) . \text { Poly- } \\
\text { phenols and COD reductions were about } 82,4 \% \text { and } 59,8 \% \text {. }\end{array}$ & $\begin{array}{l}\text { [Andreozzi et al. } \\
\text { 2008] }\end{array}$ \\
\hline Ozonation & Winery wastewaters & $\begin{array}{l}\text { The ozone dose rate } 0.68 \mathrm{~g} / \mathrm{h} / \mathrm{L}, \mathrm{pH} 4 \text {. Ozonation reduced } \\
\text { the initial COD by } 12 \% \mathrm{At} \mathrm{pH} 4 \text {, ozone does not decompose } \\
\text { to more reactive radical species, therefore the COD removal } \\
\text { was limited. }\end{array}$ & [Lucas et al. 2010] \\
\hline $\begin{array}{l}\text { Ozonation with con- } \\
\text { ventional aerobic } \\
\text { oxidation }\end{array}$ & Distillery wastewater & $\begin{array}{l}\text { Ozone was found to be effective in bringing down the COD } \\
\text { (up to } 27 \% \text { ) during the pretreatment step itself. The inte- } \\
\text { grated process achieved } \sim 79 \% \text { COD reduction along with } \\
\text { decoloration of the effluent sample as compared to } 34.9 \% \\
\text { COD reduction for non-ozonated sample, over a similar } \\
\text { treatment period. }\end{array}$ & $\begin{array}{l}\text { [Sangave et al. } \\
\text { 2007] }\end{array}$ \\
\hline Ozonation & Synthetic melanoidins & $\begin{array}{l}\text { As it can be observed, it achieves very significant removals } \\
\text { of COD and TOC (>80\% and }>70 \% \text {, respectively) and the } \\
\text { almost complete disappearance of the color (ozone produc- } \\
\text { tion: } 1 \mathrm{~g} / \mathrm{h}, 25^{\circ} \mathrm{C}, \mathrm{pH} 12 \text {, time change) }\end{array}$ & $\begin{array}{c}\text { [Canizares et al. } \\
\text { 2006] }\end{array}$ \\
\hline Ozonation & $\begin{array}{l}\text { Molasses fermentation } \\
\text { wastewater }\end{array}$ & $\begin{array}{l}\text { The highest efficiencies were achieved at } 40{ }^{\circ} \mathrm{C} \text { (the ozone } \\
\text { dose rate constants }=2.3 \mathrm{~g} / \mathrm{h} / \mathrm{L} \text { ). Color and COD reductions } \\
\text { were about } 90 \% \text { and } 37 \% \text {, respectively. In no case, the } \\
\text { percentage of TOC removed was higher than } 10-15 \% \text {. }\end{array}$ & [Coca et al. 2005] \\
\hline
\end{tabular}
with a wide range of organic and inorganic com-

Table 4. A brief summary of research studies in which ozonation were used for treating food industry wastewater 
pounds in water (i.e., indirect ozonation pathway) [Meriç et al. 2005, Pera-Titus et al. 2004, Turhan \& Turgut 2009].

Ozone has many properties desirable for the treatment of the wastewater [Gogate \& Pandit 2004, Rizzo 2011]:

- no sludge remains,

- danger is minimal,

- decolorization and degradation occur in one step,

- it is easily performed,

- little space is required,

- all residual ozone can be easily decomposed to oxygen and water.

Ozonation has been successfully applied to the treatment of winery and distillery wastewater [Zaleska \& Grabowska 2008], olive mile wastewater [Oller et al. 2011], meat industry wastewater [Millamena 1992], molasses wastewater [Coca et al. 2007] etc.

\section{Photocatalytic process}

The photocatalytic or photochemical degradation processes are gaining importance in the area of wastewater treatment, since these processes result in complete mineralization with operation at mild conditions of temperature and pressure [Tarek et al. 2011, Ugurlu \& Karaoglu 2011]. In the process, semiconductor material is excited by electromagnetic radiation possessing energy of sufficient magnitude, to produce conduction band electrons and valence band holes [Gogate \& Pandit 2004, Stasinakis 2008, Żmudziński 2010].

The selection of the adequate catalyst must consider the following properties: chemical activity, stability, availability and handiness, cost and lack of toxicity [Navarro et al. 2005]. The surface area and the number of active sites offered by the catalyst (thus nature of catalyst, i.e. crystalline or amorphous is important) for the adsorption of pollutants plays an important role in deciding [Gogate \& Pandit 2004]. Several catalytic materials have been studied in photocatalysis (various oxides such as $\mathrm{TiO}_{2}, \mathrm{ZnO}, \mathrm{SnO}_{2}, \mathrm{WO}_{3}, \mathrm{ZrO}_{2}, \mathrm{CeO}$ etc. or sulfides such as $\mathrm{CdS}, \mathrm{ZnS}$ etc.) [Gogate \& Pandit 2004, Sakthivel et al. 2003, Habibi et al. 2001]. Among the semiconductors reported so far, outstanding stability and oxidative power makes $\mathrm{TiO}_{2}$, the best semiconductor photocatalyst for environmental remediation and energy conversion processes [Gogate \& Pandit 2004, Ugurlu \& Karaoglu 2011, Navarro et al. 2005, Chatzi- symeon et al. 2008, Banu et al. 2008]. However, there are two potential drawbacks associated with the use of $\mathrm{TiO}_{2}$, namely: (a) its possible toxic effects on human health and (b) reduced activity due to the complexity of water matrix (i.e., presence of solids or inorganic ions) [Chatzisymeon et al. 2008].

$\mathrm{TiO}_{2}$ in its anatase form has an energy bandgap of $3.2 \mathrm{eV}$ and can be activated by UV radiation with a wavelength up to $387.5 \mathrm{~nm}$. It only requires $1 \mathrm{~W} / \mathrm{m}^{2}$ of light [Navarro et al. 2005, Navgire 2012]. Photocatalytic degradation occurs through a multistep process that involves the formation of reactive species on the surface of the photocatalyst and the subsequent generation of hydroxyl radicals that result in the mineralization of most organic compounds [Navarro et al. 2005, Chatzisymeon et al. 2008, Banu et al. 2008, Navgire et al. 2012]. The photocatalysis can be explained by the following simplified reaction (with $\mathrm{TiO}_{2}$ ) [Stasinakis 2008, Navarro et al. 2005]:

$$
\begin{gathered}
\mathrm{TiO}_{2}+\mathrm{hv} \rightarrow \mathrm{e}^{-}+\mathrm{h}^{+} \\
\mathrm{e}^{-}+\mathrm{O}_{2} \rightarrow \mathrm{O}_{2}^{-\cdot} \\
\mathrm{h}^{+}+\mathrm{H}_{2} \mathrm{O} \rightarrow \mathrm{H}++\mathrm{HO}^{\cdot} \\
\mathrm{h}^{+}+\mathrm{OH}^{-} \rightarrow \mathrm{HO}^{\cdot} \\
\mathrm{O}_{2}^{-\cdot}+\mathrm{H}^{+} \rightarrow \mathrm{HO}_{2}^{\cdot}
\end{gathered}
$$

The UV radiation required for the photocatalytic processes can be obtained from artificial sources or the sun. There is a significant economic incentive for solar light based photocatalytic degradations [Banu et al. 2008].

The major factors affecting $\mathrm{TiO}_{2} / \mathrm{UV}$ light process are: initial organic load, amount of catalyst, reactor's design, UV irradiation time, temperature, solution's $\mathrm{pH}$, light intensity and the presence of ionic species. The use of excessive amounts of catalyst may reduce the amount of energy being transferred into the medium due to the opacity offered by the catalyst particles [Stasinakis 2008]. Organic compounds can then undergo both oxidative degradation through their reactions with valence band holes, hydroxyl and peroxide radicals and reductive cleavage through their reactions with electrons yielding various by-products and eventually mineral end-products [Gogate \& Pandit 2004, Ugurlu \& Karaoglu 2011, Chatzisymeon et al. 2008]. In several studies, photocatalytic process has been used to the treatment of winery and distillery wastewater [Lucas et al. 2009], olive mile wastewater [Chatzisymeon et al. 2008], dairy industry wastewater [Banu et al. 2008], molasses wastewater [Satyawali \& 
Table 5. A brief summary of research studies in which photocatalytic process were used for treating food industry wastewater

\begin{tabular}{|c|c|c|c|}
\hline $\begin{array}{c}\text { Biological and chemi- } \\
\text { cal treatment }\end{array}$ & Target wastewater & Concluding remarks & References \\
\hline $\mathrm{UV} / \mathrm{H}_{2} \mathrm{O}_{2} / \mathrm{TiO}_{2} / \mathrm{Sep}$ & Olive mill wastewater & $\begin{array}{l}\text { Optimum values of catalyst dose, temperature and } \mathrm{H}_{2} \mathrm{O}_{2} \\
\text { were found to be } 318 \mathrm{~K} \text { and } 0.25 \text { and } 0.50 \mathrm{~g} / \mathrm{L}, 30 \mathrm{ml} / \mathrm{L} \mathrm{H}_{2} \mathrm{O}_{2} \text {, } \\
\text { respectively. The degradation of lignin and phenol was favour- } \\
\text { able at } \mathrm{pH} 9-11.0 \text { and natural sunlight. All pollutants could be } \\
\text { removed under } 24 \mathrm{~h} \text { in } 80-100 \% \text { rates. }\end{array}$ & $\begin{array}{l}\text { [Ugurlu \& Kara- } \\
\text { oglu 2011] }\end{array}$ \\
\hline Calcined $\operatorname{InYO}_{3}$ & $\begin{array}{l}\text { Molasses fermentation } \\
\text { wastewater }\end{array}$ & $\begin{array}{l}\text { Specifically, InYO } \mathrm{Y}_{3} \text { calcined at } 700{ }^{\circ} \mathrm{C} \text { had a considerably } \\
\text { larger surface area and lower reflectance intensity and } \\
\text { showed higher photocatalytic activity. After } 150-\text { min reac- } \\
\text { tion, the decolorization and COD removal were } 98.23 \% \text { and } \\
92.98 \% \text {, respectively. }\end{array}$ & [Qin et al. 2011] \\
\hline $\begin{array}{c}\text { Vacuum } \\
\text { ultraviolet } / \mathrm{TiO}_{2}\end{array}$ & $\begin{array}{l}\text { Oily wastewater } \\
\text { from the restaurant }\end{array}$ & $\begin{array}{l}\text { Under the optimum conditions of irradiation } 10 \mathrm{~min} \text {, initial } \\
\mathrm{COD} 3981 \mathrm{mg} / \mathrm{L}, \mathrm{TiO}_{2} 150 \mathrm{mg} / \mathrm{L}, \mathrm{pH} 7.0 \text { and flow rate of air } \\
40 \mathrm{~L} / \mathrm{h} \text {, the process } \mathrm{TiO}_{2} / \mathrm{VUV} \text { achieved removal efficiencies of } \\
\mathrm{COD}, \mathrm{BOD}_{5} \text { and oil about } 63 \%, 43 \%, 70 \% \text {. }\end{array}$ & [Kang et al. 2011] \\
\hline $\mathrm{TiO}_{2} / \mathrm{H}_{2} \mathrm{O}_{2}$ & $\begin{array}{l}\text { Black table olive pro- } \\
\text { cessing wastewater }\end{array}$ & $\begin{array}{l}\mathrm{TiO}_{2} \text { and } \mathrm{H}_{2} \mathrm{O}_{2} \text { concentrations in the range } 0.25-2 \mathrm{~g} / \mathrm{L} \text { and } \\
0.025-0.15 \mathrm{~g} / \mathrm{L} \text {. Depending on the conditions employed, } \\
\text { nearly complete decoloration }(>90 \%) \text { could be achieved, while } \\
\text { mineralization never exceeded } 50 \% \text {. }\end{array}$ & $\begin{array}{l}\text { [Chatzisymeon } \\
\text { et al. 2008] }\end{array}$ \\
\hline $\mathrm{TiO}_{2} / \mathrm{H}_{2} \mathrm{O}_{2}$ & Winery wastewater & $\begin{array}{l}\text { The maximum COD removal were achieved at zero catalyst } \\
\text { loading with COD removal of about } 84 \% \text {. Lower rates of } \\
\text { chemical reaction in photocatalysis compared to photolysis } \\
\text { were possibly because of the shielding of UV light by titania } \\
\text { particles. }\end{array}$ & $\begin{array}{c}\text { [Agustina et al. } \\
\text { 2008] }\end{array}$ \\
\hline $\begin{array}{c}\mathrm{TiO}_{2} / \mathrm{H}_{2} \mathrm{O}_{2} \\
\mathrm{TiO}_{2} / \mathrm{Fe} \text {-clays }\end{array}$ & Winery wastewater & $\begin{array}{l}\text { The } \mathrm{TiO}_{2} / \mathrm{H}_{2} \mathrm{O}_{2} \text { treatment produces the highest efficiency, } \\
\text { reaching to } 52-58 \% \text { of } \mathrm{COD} \text {. The optimum dosage is: } 2.5 \\
\mathrm{~mL} / \mathrm{L} \mathrm{H}_{2} \mathrm{O}_{2} \text { and } 1.0 \mathrm{~g} / \mathrm{L} \mathrm{TiO}_{2} \text {. Secondly, although the } \mathrm{H}_{2} \mathrm{O}_{2} / \text { clays } \\
\text { system produces lower } \mathrm{COD} \text { removal } 34-45 \% \text {, it requires a } \\
\mathrm{H}_{2} \mathrm{O}_{2} \text { dosage between three and six times lower than the } \mathrm{TiO}_{2} / \\
\mathrm{H}_{2} \mathrm{O}_{2} \text { treatment. }\end{array}$ & $\begin{array}{l}\text { [Navarro et al. } \\
\text { 2005] }\end{array}$ \\
\hline $\mathrm{TiO}_{2} / \mathrm{UV}$ & $\begin{array}{l}\text { Fresh-Cut Vegetable } \\
\text { Industry wastewater }\end{array}$ & $\begin{array}{l}\text { Photocatalysis was an effective disinfection method, reduc- } \\
\text { ing counts of bacteria, molds, and yeasts. Most of the treated } \\
\text { wash waters had total bacteria reductions of } 4.1 \pm 1.3 \text { to } \\
4.8 \pm 0.4 \mathrm{log} \text { CFU/ml after } 10 \text { min of treatment when compared } \\
\text { with untreated water. That implementation of } \mathrm{TiO}_{2} / \mathrm{UV} \text { in the } \\
\text { wash waters could allow the reuse of wash water. }\end{array}$ & $\begin{array}{l}\text { [[Selma et al. } \\
\text { 2008] }\end{array}$ \\
\hline $\mathrm{MoO}_{3} / \mathrm{TiO}_{2} / \mathrm{UV}$ & Molasses wastewater & $\begin{array}{l}\text { The color of the molasses solution decreases to around } 70 \% \text {, } \\
\text { The maximum decreases in COD, BOD, and TDS about } 90 \% \text {, } \\
90 \%, 50 \% \text {, respectively. This system rate increases with an } \\
\text { increase in temperature from } 40 \text { to } 80{ }^{\circ} \mathrm{C} \text {. }\end{array}$ & $\begin{array}{l}\text { [Navgire et al. } \\
\text { 2012] }\end{array}$ \\
\hline
\end{tabular}

Balakrishnan 2008], candy and sugar industry wastewater [Żmudziński 2010], fresh-cut vegetable industry wastewater [Selma et al. 2007] etc. Several applications are presented below (Table 5).

\section{THE COMBINATION OF AOP'S FOR WASTEWATER TREATMENT}

Differently combined AOP's have been developed and investigated by several research groups as alternatives for treating food industrial wastewater containing organic pollutants. This may commonly cause a reduction of toxicity or elimination of a specific pollutant or reduce the reaction time and economic cost [Oller et al. 2011, Stasinakis 2008, de Sena et al. 2009, Zayas et al. 2007].
Determining the target is an essential step in combination studies since it helps define process efficiency and provides a basis for comparing different operating conditions and optimizing the process [Oller et al. 2011, Stasinakis 2008].

\section{CONCLUSION}

Food industry uses large amounts of water for many different purposes including cooling and cleaning, as a raw material, as sanitary water for food processing, for transportation, cooking and dissolving, as auxiliary water etc. In principle, the water used in the food industry may be used as process and cooling water or boiler feed water. As a consequence of diverse consumption, the amount and composition of 
Table 6. A brief summary of research studies in which combining various AOP's were used for treating food industry wastewater

\begin{tabular}{|c|c|c|c|}
\hline $\begin{array}{l}\text { Biological and chemical } \\
\text { treatment }\end{array}$ & Target wastewater & Concluding remarks & References \\
\hline $\begin{array}{l}\text { Diamond electrochemical } \\
\text { oxidation } \\
\text { Fenton-ozonation }\end{array}$ & $\begin{array}{l}\text { Synthetic melanoidins } \\
\text { solution }\end{array}$ & $\begin{array}{l}\text { Operation conditions - CDEO: natural } \mathrm{pH} ; \mathrm{T}: 25^{\circ} \mathrm{C} ; \mathrm{j}: 300 \\
\mathrm{~A} \cdot \mathrm{cm}^{-2} \text {. Ozone production: } 1 \mathrm{~g} / \mathrm{h}, \mathrm{T}: 25^{\circ} \mathrm{C} ; \mathrm{pH} 12 \text {. Fenton } \\
\text { process: } \mathrm{pH} \text { 3; } \mathrm{T}: 25^{\circ} \mathrm{C} ; \mathrm{Fe}^{2+}: 667 \mathrm{mg} / \mathrm{dm}^{-3} \text {. Complete min- } \\
\text { eralization of the waste is obtained and no refractory com- } \\
\text { pounds remain at the end of the process in both cases. }\end{array}$ & $\begin{array}{l}\text { [Canizares } \\
\text { et al. 2009] }\end{array}$ \\
\hline $\begin{array}{l}\text { sonication/ } \\
\text { anaerobic fermentation }\end{array}$ & Cassava wastewater & $\begin{array}{l}\text { Hydrogen yield for cassava wastewater pretreated at } \\
\text { pH } 7.0 \text { with sonication for } 45 \text { min using anaerobic seed } \\
\text { sludge was } 0.913 \mathrm{~mol} \mathrm{H}_{2} / \mathrm{g} \text { COD. In wastewater COD } \\
\text { removal was } 40 \% \text {. }\end{array}$ & $\begin{array}{l}\text { [Leaño et al. } \\
\text { 2012] }\end{array}$ \\
\hline UD,ozonation & $\begin{array}{l}\text { Thermally pretreated } \\
\text { distillery wastewater }\end{array}$ & $\begin{array}{l}\text { The study clearly shows the suitability of ozone and ultra- } \\
\text { sound as a pre-treatment step for the thermally pretreated } \\
\text { wastewater for aerobic treatment by increasing the COD } \\
\text { removal efficiency. Ozone was more efficient in COD } \\
\text { removal with a } 25 \text {-times increase in the rate of biodegra- } \\
\text { dation of ozonated sample along with discoloration of the } \\
\text { effluent sample. }\end{array}$ & $\begin{array}{l}\text { [Sangave } \\
\text { et al. 2007] }\end{array}$ \\
\hline $\mathrm{UV} / \mathrm{H}_{2} \mathrm{O}_{2} / \mathrm{O}_{3}$ & Coffee wastewater & $\begin{array}{l}\text { The UV/ } / \mathrm{H}_{2} \mathrm{O}_{2} / \mathrm{O}_{3} \text { process is capable of reducing the COD } \\
\text { content of the wastewater by } 87 \% \text { in } 35 \text { min at } \mathrm{pH} 2.0 \text {. By } \\
\text { comparison, the } \mathrm{UV} / \mathrm{H}_{2} \mathrm{O}_{2} \text { and UV/O } / \mathrm{O}_{3} \text { treatments under the } \\
\text { same conditions reduced the COD by approximately } 84 \% \text {. }\end{array}$ & $\begin{array}{l}\text { [Zayas et al. } \\
\text { 2007] }\end{array}$ \\
\hline $\mathrm{UV} / \mathrm{H}_{2} \mathrm{O}_{2} / \mathrm{O}_{3}$ & Winery wastewater & $\begin{array}{l}\text { The COD removal efficiency is slightly higher at } \mathrm{pH} 10 \\
(57 \%) \text {, than } \mathrm{pH} 4(49 \%) \text { and } \mathrm{pH} 7(40 \%) \text { after } 300 \mathrm{~min} \text {. }\end{array}$ & $\begin{array}{l}\text { [Lucas et al. } \\
\text { 2010] }\end{array}$ \\
\hline $\begin{array}{l}\text { Dissolved air flotation } \\
\text { (DAF) with UV/ } \mathrm{H}_{2} \mathrm{O}_{2} \text { or } \\
\text { photo-Fenton }\end{array}$ & $\begin{array}{l}\text { Meat industry waste- } \\
\text { water }\end{array}$ & $\begin{array}{l}\mathrm{DAF} / \mathrm{UV} / \mathrm{H}_{2} \mathrm{O}_{2} \text { results for } \mathrm{BOD}_{5} \text { and } \mathrm{COD} \text { reduction was } \\
82.9 \% \text { and } 91.1 \% \text { respectively. For TS and VS, reductions } \\
\text { of up to } 72.5 \% \text { and } 77.0 \% \text { were achieved, respectively. } \\
\text { DAF/photo-Fenton results for } \mathrm{BOD}_{5} \text { and COD reduction } \\
\text { was } 95.7 \% \text { and } 97.61 \% \text { respectively. For TS and VS, } \\
\text { reductions of up to } 61.5 \% \text { and } 90.8 \% \text { were achieved, } \\
\text { respectively. }\end{array}$ & $\begin{array}{l}\text { [de Sena } \\
\text { et al. 2009] }\end{array}$ \\
\hline $\mathrm{UV} / \mathrm{H}_{2} \mathrm{O}_{2}$ & Synthetic melanoidin & $\begin{array}{l}\text { The oxidation process was much more capable of remov- } \\
\text { ing color } 99 \% \text {, dissolved organic carbon (DOC) } 50 \% \text { and } \\
\text { dissolved organic nitrogen (DON) } 25 \% \text { at the optimal } \\
\text { applied dose of } \mathrm{H}_{2} \mathrm{O}_{2} \text { for the system }(3.3 \mathrm{~g} / \mathrm{L})\end{array}$ & $\begin{array}{l}\text { [Dwyer et al. } \\
\text { 2008] }\end{array}$ \\
\hline $\mathrm{UV} / \mathrm{O}_{3}$ & Olive mill wastewater & $\begin{array}{l}\text { In particular, biodegradation of } \mathrm{UV} / \mathrm{O}_{3} \text { pretreated OMW } \\
\text { found to have the highest removal levels; the percent of } \\
\text { COD removal reaches about } 91 \% \text {. }\end{array}$ & [Lafi et al. 2009] \\
\hline $\begin{array}{l}\text { Modified photo-Fenton } \\
\text { /ozonation }\end{array}$ & Olive mill wastewater & $\begin{array}{l}\text { For Fe(III)/air/solar light and ozonation the highest ef- } \\
\text { ficiencies Polyphenols and COD reductions were about } \\
87.9 \% \text { and } 64.9 \% \text {. }\end{array}$ & $\begin{array}{l}\text { [Andreozzi } \\
\text { et al. 2008] }\end{array}$ \\
\hline
\end{tabular}

food industry wastewaters varies considerably. Characteristics of the effluent consist of large amounts of suspended solids, nitrogen in several chemical forms, fats and oils, phosphorus, chlorides and organic matter.

AOP's constitute a promising technology for the treatment of food industry wastewaters containing difficult to biodegradable organic contaminants. It involves the generation of free hydroxyl radical $\left(\mathrm{HO}^{\circ}\right)$, a powerful, nonselective chemical oxidant to change organic compounds to a more biodegradable form or of carbon dioxide and water. These processes can reduce a broad spectrum of chemical and biological contaminants which are otherwise difficult to remove with conventional treatment processes of food industry wastewater.

\section{Acknowledgments}

This work was supported by the Faculty of Environmental Protection and Engineering, Czestochowa University of Technology (project BS/ MN-401-315/11).

\section{REFERENCES}

1. Agustina T.E., Ang H.M., Pareek V.K. 2008. Treatment of winery wastewater using a photocatalytic/ photolytic reactor. Chem. Eng. J., 135 (1-2), 151-156.

2. Altinbas M., Aydin A.F., Sevimli M.F., Ozturk I. 2003. Advanced oxidation of biologically pretreated Baker's Yeast Industry effluents for high recalcitrant COD and color removal. J. Environ. Sci. Health A, 38 (10), 2229-2240. 
3. Álvarez P.M., Pocostales J.P., Beltrán F.J. 2011. Granular activated carbon promoted ozonation of a food-processing secondary effluent. J. Hazard. Mater., 185, 776-783.

4. Amora C., Lucasa M.S., Pirraa A.J., Peresa J.A. 2012. Treatment of concentrated fruit juice wastewater by the combination of biological and chemical processes. J. Environ. Sci. Health A, 47 (12), 1809-1817.

5. Andreozzi R., Canterino M., Di Somma I., Lo Giudice R., Marotta R., Pinto G., Pollio A. 2008. Effect of combined physico-chemical processes on the phytotoxicity of olive mill wastewaters. Wat. Res., 42, 1684-1692.

6. Banu J.R., Anandan S., Kaliappan S., Yeom I-Y. 2008. Treatment of dairy wastewater using anaerobic and solar photocatalytic methods. Sol. Energy, $82,812-819$.

7. Bayramoglu M., Kobya M., Eyvaz M., Senturk E. 2006. Technical and economic analysis of electrocoagulation for the treatment of poultry slaughterhouse wastewater. Sep. Purif. Technol., 51, 404-408.

8. Beltran-Heredia J., Torregrosa J.,Dominguez J.R., Garcia J. 2000. Treatment of black-olive wastewaters by ozonation and aerobic biological degradation. Wat. Res., 34 (14), 3515-3522.

9. Calvo L.S., Leclerc J.P., Tanguy G., Cames M.C., Paternotte G., Valentin G., Rostan A., Lapicque F. 2003. An electrocoaguhtion unit for the purification of soluble oil wastes of high COD. Environ. Prog., 22, 57-65.

10. Canizares P., Hernández-Ortega M., Rodrigo M.A., Barrera-Díaz C.E., Roa-Morales G., Sáez C. 2009. A comparison between conductive-diamond electrochemical oxidation and other advanced oxidation processes for the treatment of synthetic melanoidins. J. Hazard. Mater., 164, 120-125.

11. Chatzisymeon E., Stypas E., Bousios S., Xekoukoulotakis N.P., Mantzavinos D. 2008. Photocatalytic treatment of black table olive processing wastewater. J. Hazard. Mater., 154, 1090-1097.

12. Chen X., Chen G., Yue P.L. 2000. Separation of pollutants from restaurant wastewater by electrocoagulation. Sep. Purif. Technol., 19, 65-76.

13. Cicek N. 2003. A review of membrane bioreactors and their potential application in the treatment of agricultural wastewater. CSBE, 43, 37-49.

14. Coca M., Pena M., Gonzalez G. 2007. Kinetic study of ozonation of molasses fermentation wastewater. J. Hazard. Mater., 149, 364-370.

15. Coca M., Pena M., Gonzalez G. 2005. Variables affecting efficiency of molasses fermentation wastewater ozonation. Chemosphere, 60, 1408-1415.

16. de Sena F.R., Tambosi J.L., Genena A.K., Moreira R., Schröder H.F., José H.J. 2009. Treatment of meat industry wastewater using dissolved air flotation and advanced oxidation processes monitored by GC-MS and LC-MS. Chem. Eng. J., 152, 151-157.

17. Durán A., Monteagudo J.M., Carnicer A. 2011. Photo-Fenton mineralization of synthetic applejuice wastewater. Chem. Eng. J., 168, 102-107.

18. Elaoud S.Ch., Panizza M., Cerisola G., Mhiri T. 2011. Electrochemical degradation of sinapinic acid on a BDD anode. Desalination, 272, 148-153.

19. Gengec E., Kobya M., Demirbas E., Akyol A., Oktor K. 2012. Optimization of baker's yeast wastewater using response surface methodology by electrocoagulation. Desalination, 286, 200-209.

20. Gogate P.R., Pandit A.B. 2004. A review of imperative technologies for wastewater treatment: Oxidation technologies at ambient conditions. Advances in Environmental Research, 8 (3-4), 501-551.

21. Habibi, M.H., Tangestaninejad, S., Yadollahi, B. 2001. Photocatalytic mineralisation of mercaptans as environmental pollutants in aquatic system using $\mathrm{TiO}_{2}$ suspension. Appl. Catal. B-Environ., 33 (1), 57.

22. Hanafi F., Assobhei O., Mountadar M., Detoxification and discoloration of Moroccan olive mill wastewater by electrocoagulation. J. Hazard. Mater., 2010, 174, 807-812.

23. Herney-Ramirez J., Vicente M.A., Madeira L.M. 2010. Heterogeneous photo-Fenton oxidation with pillared clay-based catalysts for wastewater treatment: A review. Appl. Catal. B-Environ., 98, $10-26$.

24. Kang J-X., Lu L., Zhan W., Li B., Li D-S., Ren Y-Z., Liu D-Q. 2011. Photocatalytic pretreatment of oily wastewater from the restaurant by a vacuum ultraviolet/ $/ \mathrm{TiO}_{2}$ system. J. Hazard. Mater., 186, 849-854.

25. Kannan N., Karthikeyan G., Tamilselvan N. 2006. Comparison of treatment potential of electrocoagulation of distillery effluent with and without activated Areca catechu nut carbon. J. Hazard. Mater., 137, 1803-1809.

26. Khoufi, S., Aloui, F., Sayadi, S., Pilot scale hybrid process for olive mill wastewater treatment and reuse. Chem. Eng. Process., 2009, 48 (2), 643-650.

27. Kobya M., Delipinar S. 2008. Treatment of the baker's yeast wastewater by electrocoagulation. J. Hazard. Mater., 154, 1133-1140.

28. Kobya M., Hiz H., Senturk E., Aydiner C., Demirbas E. 2006. Treatment of potato chips manufacturing wastewater by electrocoagulation. Desalination., 190, 201-211.

29. Lafi W.K., Shannak B., Al-Shannag M., Al-Anber Z., Al-Hasan M. 2009. Treatment of olive mill wastewater by combined advanced oxidation and biodegradation. Sep. Purif. Technol., 70, 141-146. 
30. Leaño E.P., Babel S. 2012. Effects of pretreatment methods on cassava wastewater for biohydrogen production optimization. Renew. Energ., 39, 339-346.

31. Ledakowicz S., Solecka M., Zylla R. 2001. Biodegradation, decolourisation and detoxification of textile wastewater enhanced by advanced oxidation processes. J. Biotechnol., 89, 175-184.

32. Lee H., Shoda M. 2008. Removal of COD and colour from livestock wastewater by the Fenton method. J. Hazard. Mater., 153, 1314-1319.

33. Lucas M.S., Peres J.A., Puma G.L. 2010. Treatment of winery wastewater by ozone-based advanced oxidation processes $\left(\mathrm{O}_{3}, \mathrm{O}_{3} / \mathrm{UV}\right.$ and $\mathrm{O}_{3} /$ $\mathrm{UV} / \mathrm{H}_{2} \mathrm{O}_{2}$ ) in a pilot-scale bubble column reactor and process economics. Sep. Purif. Technol., 72, 235-241.

34. Lucas M.S., Mosteo R., Maldonado M.I., Malato S., Peres J.A. 2009. Solar photochemical treatment of winery wastewater in a CPC reactor. J. Agric. Food Chem., 57 (23), 11242-11248.

35. Marcucci M., Ciardelli G., Matteucci A., Ranieri L., Russo M. 2002. Experimental campaigns on textile wastewater for reuse by means of different membrane processes. Desalination, 149 (1-3), 137-143.

36. Martins R.C., Quinta-Ferreira R.M. 2011. Remediation of phenolic wastewaters by advanced oxidation processes (AOPs) at ambient conditions: Comparative studies. Chem. Eng. Sci., 66, 3243-3250.

37. Mason T.J. 2000. Large scale sonochemical processing: aspiration and actuality. Ultrason. Sonochem., 7(4), 145-149.

38. Mavrov V., Belieres E. 2000. Reduction of water consumption and wastewater quantities in the food industry by water recycling using membrane processes. Desalination, 131, 75-86.

39. Meriç S., Selçuk H., BelgiornoV. 2005. Acute toxicity removal in textile finishing wastewater by Fenton's oxidation, ozone and coagulation-flocculation processes. Wat. Res., 39 (6), 1147-1153.

40. Mert B.K., Yonar T., Kilic M.Y., Kestioglu K. 2010. Pre-treatment studies on olive oil mill effluent using physicochemical Fenton and Fentonlike oxidations processes. J. Hazard. Mater., 174, 122-128.

41. Millamena O.M. 1992. Ozone treatment of slaughterhouse and laboratory wastewaters. Aquacult. Eng., 11 (1), 23-31.

42. Monteagudo J.M., Durán A., Corral J.M., Carnicer A., Frades J.M., Alonso M.A. 2012. Ferrioxalateinduced solar photo-Fenton system for the treatment of winery wastewaters. Chem. Eng. J., 181182, 281-288.

43. Muñoz I., Rieradevall J., Torrades F., Peral J., Doménech X. 2005. Environmental assessment of dif- ferent solar driven advanced oxidation processes. Sol. Energy, 79 (4), 369-375.

44. Navarro P., Sarasa J., Sierra D., Esteban S., Ovelleiro J.L. 2005. Degradation of wine industry wastewaters by photocatalytic advanced oxidation. Water Sci. Technol., 51 (1), 113-120.

45. Navgire M., Yelwande A., Tayde D., Arbad B., Lande M. 2012. Photodegradation of Molasses by a $\mathrm{MoO}_{3}-\mathrm{TiO}_{2}$ Nanocrystalline Composite Material. Chin. J. Catal., 33, 261-266.

46. Oller I., Malato S., Sánchez-Pérez J.A. 2011. Combination of Advanced Oxidation Processes and biological treatments for wastewater decontamination - A review. Sci. Total Environ., 409 (20), 4141-4166.

47. Pala A., Erden G. 2005. Decolorization of a baker's yeast industry effluent by Fenton oxidation. J. Hazard. Mater. B, 127, 141-148.

48. Pera-Titus M., García-MolinaM., Baños M.A., Giménez J., Esplugas S. 2004. Degradation of chlorophenols by means of advanced oxidation processes: a general review. Appl. Catal. B-Environ., 47 (4), 219-256.

49. Pérez M., Torrades F., Doménech X., Peral J. 2002. Fenton and photo-Fenton oxidation of textile effluents. Wat. Res., 36, 2703-2710.

50. Qin Z., Liang Y., Liu Z., Jiang W. 2011. Preparation of $\mathrm{InYO}_{3}$ catalyst and its application in photodegradation of molasses fermentation wastewater. J. Environ. Sci., 23 (7), 1219-1224.

51. Rivas F.J., Beltrán F.J., Gimeno O., Alvarez P. 2003. Treatment of brines by combined Fenton's reagent-aerobic biodegradation II. Process modelling. J. Hazard. Mater., 96, 259-276.

52. Rizzo L. 2011. Bioassays as a tool for evaluating advanced oxidation processes in water and wastewater treatment. Wat. Res., 45, 4311-4340.

53. Roa-Morales G., Campos-Medina E., AguileraCotero J., Bilyeu B., Barrera-Diaz C. 2007. Aluminium electrocoagulation with peroxide applied to wastewater from pasta and cookie processing. Sep. Purif. Technol., 54, 124-129.

54. Rodrigo M.A., Canizares P., Sanchez-Carretero A., Saez C. 2010. Use of conductive-diamond electrochemical oxidation for wastewater treatment. Catal. Today, 151, 173-177.

55. Sakthivel S., Neppolia B., Shankar M.V., Arabindoo B., Palanichamy M., Murugesan V. 2003. Solar photocatalytic degradation of azo dye: comparison of photocatalytic efficiency of $\mathrm{ZnO}$ and $\mathrm{TiO}_{2}$. Sol. Energ. Mat. Sol. C., 77, 65-82.

56. Sangave P.C., Gogate P.R., Pandit A.B., Combination of ozonation with conventional aerobic oxidation for distillery wastewater treatment. Chemosphere, 2007, 68, 32-41. 
57. Sanz J., Lombraña J.I., De Luis A.M., Ortueta M., Varona F. 2003. Microwave and Fenton's reagent oxidation of wastewater. Environ. Chem. Lett., 1, 45-50.

58. Sarayu K., Swaminathan K., Sandhya S. 2007. Assessment of degradation of eight commercial reactive azo dyes individually and in mixture in aqueous solution by ozonation. Dyes Pigments, 75, 362-368.

59. Satyawali Y., Balakrishnan M. 2008. Wastewater treatment in molasses-based alcohol distilleries for COD and colour removal: A review. Journal of Environmental Management 86, 481-497.

60. Selma M.V., Allende A., López-Gálvez F., Conesa M.A., Gil M.I. 2008. Heterogeneous photocatalytic disinfection of wash waters from the freshcut vegetable industry. J. Food Protection, 71 (2), 286-292.

61. Selma M.V., AllendeA., López-Gálvez F., Gil M.I. 2007. Different advanced oxidation processes for disinfection of wash waters from the fresh-cut industry. IOA Conference and Exhibition Valencia, Spain, 6.1, 1-8.

62. Shu H. 2006. Degradation of dyehouse effluent containing C.I. Direct Blue 199 by processes of ozonation, $\mathrm{UV} / \mathrm{H}_{2} \mathrm{O}_{2}$ and in sequence of ozonation with $\mathrm{UV} / \mathrm{H}_{2} \mathrm{O}_{2}$. J. Hazard. Mater., 133, 92-98.

63. Stasinakis A.S., Use of selected advanced oxidation processes (AOPs) for wastewater treatment - a mini review. Global NEST Journal, 2008, 10 (3), 376-385.

64. Tarek S. Jamil, Montaser Y. Ghaly, Ibrahim E. ElSeesy, Eglal R. Souaya, Rabab A. Nasr 2011. A comparative study among different photochemical oxidation processes to enhance the biodegradability of paper mill wastewater. J. Hazard. Mater., $185,353-358$.

65. Tokumura M., Ohta A., Znad H.T., Kawase Y. 2006. UV light assisted decolorization of dark brown colored coffee effluent by photo-Fenton reaction. Wat. Res., 40, 3775-3784.

66. Tokumura M., Znad H.T., Kawase Y. 2008. Decolorization of dark brown colored coffee effluent by solar photo-Fenton reaction: Effect of solar light dose on decolorization kinetics. Wat. Res., 42, 4665-4673.
67. Turhan K., Turgut Z. 2009. Decolorization of direct dye in textile wastewater by ozonization in a semi-batch bubble column reactor. Desalination, 242, 256-263.

68. Ugurlu M., Karaoglu M.H. 2011. TiO 2 supported on sepiolite: Preparation, structural and thermal characterization and catalytic behaviour in photocatalytic treatment of phenol and lignin from olive mill wastewater. Chem. Eng. J., 166, 859-867.

69. Ulson de Souza S.M., Santos Bonilla K.A., Ulson de Souza A.A. 2010. Removal of COD and colour from hydrolyzed textile azo dye by combined ozonation and biological treatment. J. Hazard. Mater., 179 (1-3), 35-42.

70. Ün Ü.T., Koparal A.S., Ögütveren Ü.B. 2009. Hybrid processes for the treatment of cattle-slaughterhouse wastewater using aluminum and iron electrodes. J. Hazard. Mater., 164, 580-586.

71. Wu J., Doan H. 2005. Disinfection of recycled redmeat-processing wastewater by ozone. J. Chem. Technol. Biotechnol., 80, 828-833.

72. Xu L.J., Sheldon B.W., Larick D.K., Carawan R.E. 2002. Recovery and utilization of useful by-products from egg processing wastewater by electrocoagulation. Poultry Sci., 81, 785-792.

73. Zaleska A., Grabowska E. 2008. Podstawy technologii chemicznej. Nowoczesne procesy utleniania - ozonowanie, utlenianie fotokatalityczne, reakcja Fentona. Politechnika Gdańska, Gdańsk.

74. Zayas P.T., Geissler G., Hernandez F. 2007. Chemical oxygen demand reduction in coffee wastewater through chemical flocculation and advanced oxidation processes. J. Environ. Sci., 19, 300-305.

75. Zhukova V., Sabliy L., Łagód G. 2010. Biotechnology of the food industry wastewater treatment from nitrogen compounds. Proceedings of ECOpole, 5 (1), 133-138.

76. Żmudziński W., Preliminary results of glucose oxidation by photocatalysis on titanium dioxide primary intermediates. Physicochem. Probl. Miner. Process., 45141-45151.

77. Zorpas A.A., Costa C.N. 2010. Combination of Fenton oxidation and composting for the treatment of the olive solid residue and the olive mile wastewater from the olive oil industry in Cyprus. Bioresource Technol., 101, 7984-7987. 